\title{
Gender Discrimination: A myth or truth Women status in Pakistan
}

\author{
*Farah Yasmin Bukhari, Prof Dr. Muhammad Ramzan \\ Research Scholar, Superior University Lahore \\ Superior University Lahore
}

\begin{abstract}
Naturally human beings are divided into two genders and both are given responsibilities and rights which suit them, discrimination is the practice of granting or denying rights or offer privileges based on the gender. The aim of this study is to enrich the understanding of existence of gender discrimination in Pakistan in reality in Islamic perspective. It further explores is there any relationship between practiced gender roles in Pakistan and gender roles described in religion Islam and what are reasons of discrimination. Methodology for paper was thematic and secondary data was analyzed thematically. Qualitative data was collected based on previous literature and current reports to explore the discrimination in Pakistani culture is real or is a myth. Neutral studies about this topic were found limited. Studies are done by religious scholars in one extreme and moderate scholars on another extreme. Data was analysed using thematic analysis. The data analysis process was done using the principles recommended by Spiggle 1999) and others (Strauss and Corbin 1990; Arnould and Wallendorf, 1994) for the analysis and interpretation of qualitative data.

Key words: gender discrimination, women role, feminism in under developed countries, Islamic perspective of gender, cultural influence on gender
\end{abstract}

\section{Introduction}

Over the years women status has been studied in diverse contexts in diverse perspectives. Islamic perspective is the most misunderstood by non-muslin scholars particularly and some moderate muslims generally. Women status in Islamic countries traditionally has been seen in context of Islamization's impact on women and not in the context of their cultures and regions which they belong (Zeba A. Sathar et al 2002).

There is an established and growing body of research on Gender roles however, traditional theories encounters status of woman in Islamic perspective. The theoretical framework applied by mainstream research is clearly gendered (Ahl 2006). What impact Islamization means in Pakistan, what is the role of muslin woman expected in a muslim state, on the other hand feminist movement focused only on inadequate representation of women in Pakistan's all spheres of life to design policies to promote Pakistan an Islamic state (Rasul Bakhsh Rais 2007). In developing economies usually gender roles are largely determined by social norms \& traditions not determined by only religion of population. In all over Pakistan, existences of significant regional gender differences prove this reality (Farzana Bari; Manila 2000).

Muslim's principle book is Quran. Many verses of muslim's religion book Quran tells in text that Creator of human beings says:

"I shall not lose sight of the labor of any of you who labors in my way, be it man or woman; each of you is equal to the other (3:195)"

In the Quran accountability for men and women, spiritual equality and responsibility is a unique and well-developed theme. This spiritual equality between men and women is base of equality in all aspects of human life in the world and after world in the sight of Allah

Muslim's religious book Quran is in Arabic language. Pakistan has literacy rate 58percent in 2012, (Only 22 percent of girls, compared to 47 percent boys, complete primary schooling (Economic Survey of Pakistan 2012).This is included people who can write and read their names only. With such literacy rate it can not be expected that society will understand and obey all religious orders of Allah given in Arabic book Quran.

Given these gaps, and building on the argument that the gender discrimination is result of various cultural influences that have converged during different periods over the history: British inheritance, Indian influences (before partition), and religious and American influences (Khilji, 1999). As a result of all these influences, different cultural practices have become prevalent. Although the more than 95percent population is of Pakistan is muslim, Islamic practices are not very much prevalent; society seems influenced by history, regional traditions, religion and modernization. However, as a result of various historical transition periods, both liberal and conservative beliefs are widespread and influence the population's mindset.

Considering that our aim in this paper is to enrich understanding of if gender discrimination exists then it is result of Islamization, or cultural norms, it explores all theories and policies may have limitations but life code given by manufacturer of whole universe can not be wrong. Some of the most extreme examples of gender 
inequality in society seem as: woman's status in comparison with man's in marriage , forbidden from driving, dress code and requirements, given right of divorce to man, chances of education, mobilization, victims of violence, custody rights, citizenship, sexual subjugation, female infanticide witnessing, inheritance.

Fields of life for both genders are different not in a way of importance but for the sake of humanity and perfection of beautiful human life. We can differentiate these fields but can not grade on the basis of superiority and inferiority. To this end, we have conducted qualitative research based on previous literature. In this article, we begin by providing some context on history on women status in previous civilization. We then briefly discussed Islamic perspective, outlining contribution of Islam toward the reinstatement of woman's rights and added the literature on women rights at home and workplace. Next we discussed our methodology before examining the findings. Our discussion focuses on how cultural norms influence the status of gender and what are the reasons of gender discrimination other than religion. Finally, we conclude our paper and outline its limitations and the future research agenda.

\section{Question 1}

\section{Is there gender discrimination exist in Pakistan?}

Question 2

Are gender roles determined by society norms or by religion?

Question 3

What are reasons of gender discrimination?

\section{Literature Review}

Gender inequality means disparity among human beings on the basis of gender. Gender is differentiated basically in two ways generally, firstly social perception about status of gender secondly on the basis of biological aspects through body differences as human chromosomes, brain structure, and hormonal differences of human body. Gender inequality means differentiation, whether pragmatic grounded or social.

Today gender roles are knitted by culture and tradition but it seems that Islam influences the status of women conservatively in society and this influence slows down the progress of women, and limits the policies designed for women. This influence narrows the economic opportunities for women claimed by Robert M. Hathaway, Wilson Lee $@ 2004$.

\section{Women Status in Past Civilizations:}

To see what Islam contributed toward reinstatement of women rights actually we have to take a bird over view of status of women in ancient empires then Islamic perspective. After this we will be able to fairly evaluate the current status.

In Athens times, Allen, E. A., History of Civilization describes the status of females as "women were always minors, subject to some male - to their father, to their brother, or to some of their male kin." She was seemed to fulfill the wishes of her parents, selected by them her husband as her lord, even though he was stranger to her without her free consent for marriage.

In Roman Times According to Allen, E. A., in History of Civilization role of a woman was as a wife was according to an historian as: "a babe, a minor, a ward, a person incapable of doing or acting anything according to her own individual taste, a person continually under the tutelage and guardianship of her husband".

Encyclopedia Britannica, 1911, tells us about Legal rights of a woman in state as "In Roman Law a woman was completely dependent on her male relatives. When she got married she and her property was passed into the power of her husband ... the wife was the purchased property of her husband, and like a slave acquired only for his benefit. A woman could not exercise any civil or public office ... could not be a witness, surety, tutor, or curator; she could not adopt or be adopted, or make will or contract." (Allen, E. A., History of Civilization).

Among the Scandinavian races according to The Encyclopedia Britannica, 1911 women were: kept under permanent custody, married or unmarried. As late the Code of Christian V, till at the end of the 17th Century, if a woman got married without the consent of her guardian he can disinherit from family property during her life."

In Britain, Encyclopedia Britannica, 1968 provides some information about the rights of a married women to own property, which was amended gradually and came into in the current shape gradually under pressure of economic and social changes, as we see property right was recognized in late 19th Century, "Married Women's Property Act 1870 passed and was amended in 1882 and 1887. Women continued struggle for more rights and according to this Act married women achieved the right to own property and to enter into contracts on a par with spinsters, widows, and divorcees."

Historically in Indian according to The Encyclopedia Britannica, 1911: "In India, minds were set about subjection as a paramount principle in past. Manu says that day and night women must be held by their protectors in a state of dependence. "The rule of inheritance was agnatic, that is descent traced through males to 
the exclusion of females." Hindu woman presented as: "a subject of males, acquires high renown in this world, and, in the next, the same abode with her husband." (Mace, Marriage East and West).

The Christian women is described by Lecky, the famous historian, speaks of "these fierce incentives which form so conspicuous and so grotesque a portion of the writing of the Fathers .. "Women were disgraced because they were assumed as the door of hell, as the mother of all human ills and she should be ashamed at being a woman". "She should live in continual penance because she has brought the curses upon the world. She should be ashamed of her dress, for it is the memorial of her fall. She should be especially ashamed of her beauty, for it is the most potent instrument of the devil."

One of the most harsh and abusive criticism on women status was given in early Christian writings known as Tertullian: 'Do you know that you are each an Eve? "The sentence of God on this sex of yours lives in this age; the guilt must of necessity live too. You are the devil's gateway; you are the unsealer of that forbidden tree; you are the first deserters of the divine law; you are she who persuades him whom the devil was not valiant enough to attack." Before Christianity legal rights woman had previously enjoyed church affirm the inferior status of woman, and it influenced her status negatively and deprived her legal rights she had previously enjoyed.

\section{Foundations of Equality in Islam:}

According to the Holy Quran, men and women are equally poised: as said:

(1)" O mankind, fear your Lord, who created you from one soul and created from it its mate and dispersed from both of them many men and women... "(Quran, 4:1, 7:189, 42:11, 16:72, 32:9, and 15:29).

(2) God has invested both genders with inherent dignity and has made men and women, collectively; the trustees of God on earth (Quran 17:70 and 2:30).

(3)Every human being man or woman is equal in front of Allah and responsible for own deed as: "And their Lord responded to them (saying): Never will I allow to be lost the work of (any) worker among you, whether male or female; you are of one another... "(Quran, 3:195, 74:38, 16:97, 4:124, 33:35, and 57:12).

(4) Nobody is superior or inferior on the basis of gender as said

"The sole basis for superiority of any person over another is piety and righteousness not gender, color, or nationality" (Quran 49:13).

\section{Conventional Non Conventional and Socioeconomic Indicators of gender bias:}

1. Mobility

2. Decision Making

3. Violence

4. Mental distress and mental well-being

5. Clothing requirements

6. Right to divorce

7. Access to Education

8. Sexual subjugation

9. Female infanticide

10. Witnessing

11. Inheritance

12. Property ownership

13. Right to Contract

14. Choice of Profession

Gender inequality appears both in the workplace, at home equally in a society. We will study both Gender inequality in work place and gender Inequality At home:

\section{Gender inequality in work place:}

Mainly scholars measured gender discrimination on the basis of income disparity and social status of women as women are behaved as minorities in societies and men in a society are more benefitted in case of wages, laws, position as stated by all these scholars (Jacobs, Jerry 1995 ) and Income disparity and social status stated by Jacobs (Burstein; Paul; Edison; NJ: Aldine Transaction 1994.)

\section{The Economic Aspect of Women in Islam:}

(1) Possession of Personal Property:

Islam gave right of possess personal property and share of property in father's and husband's property which is never given before Islam and after it (even as late as this century), the right of independent ownership and possession. Women has right to hold and act as full owner of property, she has right to sell and purchase, contract and trade or lease any or all of their properties at her free will. By religious rules muslim women 
may keep (they have traditionally kept) their maiden names after marriage, is a symbol of their independent property rights as legal entities as Islamic sharia allows.

\section{(2) Financial and Inheritance Independence:}

Financial security is assured for women in Islam in her all phases of life. Woman has share in life of male relatives and gets share of property after death of male relatives (father, husband, and brother). She gets maintenance of period after divorce or death of husband called 'iddat'. She gets maintenance for child bearing also living with husband even in case of divorce. As God said in Qurran:

"For men is a share of what the parents and close relatives leave, and for women is a share of what the parents and close relatives leave, be it little or much, an obligatory share." (Quran, 4:7)

\section{(3) Right of Employment:}

According to religion of Islam first and foremost duty of a woman is to giving birth a child and trained him as a human being which live a life according to Law of Creator. This aim is such a noble cause that if it fulfills there would create an exemplary balanced society. After this priority however, getting employment is not forbidden for women, but not on the cost of her children training and other household responsibilities.

Some positions and services are fit for her nature best and biologically not difficult and in which society needs her most as nursing, teaching, medicine, and social and charitable work. Woman according to Islam is made as queen of her home not being made for market. A woman can earn if she has capability and time after her basic responsibilities.

Table 1: Employment Status, Participation and Unemployment Rate of genders

\begin{tabular}{|l|l|l|}
\hline & $2008-09$ & $2009-10$ \\
\hline Participation Rate & $32.8 \%$ & $33.0 \%$ \\
\hline Male & $49.6 \%$ & $49.5 \%$ \\
\hline Female & $14.9 \%$ & $15.5 \%$ \\
\hline & & \\
\hline Unemployment Rate & $5.5 \%$ & $5.6 \%$ \\
\hline Males & $4.5 \%$ & $4.4 \%$ \\
\hline Females & $9 \%$ & $9.5 \%$ \\
\hline Employment Status & & \\
\hline Employers & & $1.3 \%$ \\
\hline Self Employment & $1.2 \%$ & $34.2 \%$ \\
\hline Unpaid Family Helper & $33.3 \%$ & $29.1 \%$ \\
\hline Employees & $29.7 \%$ & $35.4 \%$ \\
\hline
\end{tabular}

Source: Labor Force Survey, relevant issues, Federal Bureau of Statistics

\section{The social aspect of women rights}

At home: Difference of gender roles in parenting and marriage:

According to The Qur'an, revealed to Hazrat Muhammad modified existing customs in Arab society. Hazrat Muhammad introduced reforms for rights for women in her all aspects of life like free consent in marriage \& divorce and right of property inheritance. On marriage a women got dowry for herself not for 
family, as her personal property, the Qur'an made women an equal legal party to the marriage contract. Without free consent of both (male and female) marriage is not allowed in Islam.

Quran gave the rule of inheritance with fixed shares while before Islam women were sold as commodities. It is not injustice for a woman because if she gets half and her brother full one share on the side when her husband also gets double than his sister half, so all 3 shares assembled in a single family. Islam had forbidden female infanticide clearly in Quran. It was a great change and improvement of the status of Arab women included prohibition of female infanticide and recognizing women's full personhood, stated John Esposito 2004, (Majid Khadduri in , Marriage in Islamic Law: The Modernist Viewpoints, American Journal of "Comparative Law and medieval Europe", All these admitted that Islam had introduced more rights then ever before Islam . Lindsay Jones said "women were not accorded ever with such legal status in other cultures until centuries later". After that other civilizations copied those laws and made some fundamental changes in their countries.

Professor William Montgomery Watt Interviewed, he said "when seen in such historical context, Muhammad "can be seen as a figure who testified on behalf of women's rights." (Alastairmcintosh.com. 27May 2005). Religion Islam mentioned rights for human beings muslim ,non muslims as well as relations.

1. 1.As a Daughter: There is no gender difference when a human being is: In Quran "And when the girl (who was) buried alive is asked, for what sin she was killed. "(Quran, 81:8-9)". Reaction of society on birth of baby girl is described as "And when one of them is informed of (the birth of) a female, his face becomes dark, and he suppresses grief. He hides himself from the people because of the ill of which he has been informed. Should he keep it in humiliation or bury it in the ground? Certainly, evil is what they decide. "(Quran 16:58-59)

2. As a Wife: In Islam marriage is based on mutual free consent for the obedience of creator's order and cause of peace, care, love, and companionship, and not just the mere satisfying of human sexual desire. It is described as "And of His signs is: that He created for you from yourselves mates that you may find tranquility in them; and He placed between you affection and mercy. Indeed in that are signs for a people who give thought? "(Quran, 30:21, see also 42:11 and 2:228)

Divorce is allowed but is a last resort, it is not encouraged but allowed and both have some rights about it. All details are stated in Quran "And when you divorce women and they have fulfilled their term (i.e. waiting period), either keep them in kindness or release them in kindness, and do not keep them, intending harm, to transgress (against them). " (Quran, 2:231, see also 2:229 and 33:49).

3) As a Mother: Kindness with parents is encouraged, especially with mother it is emphasized. We can see that there are no old homes in Pakistan and other muslim countries though there is poverty and other social problems are present. Respect and kindness with parents is part of religion Islam. In Quran it is ordered:

"Your Lord has commanded that you worship none but Him, and that you be kind to your parents. If one of them or both of them reach old age with you, do not say to them a word of disrespect, or scold them, but say a generous word to them. And act humbly to them in mercy, and say, "My Lord, have mercy on them, since they cared for me when I was small." (Quran, 17:23-24, see also 31:14, 46:15, and 29:8)

(4) As a Sister: The Prophet Muhammad taught kindness, care, and respect for a women in all roles in general and these rules were included in his last message at Hujat $u$ wida address given shortly before his passing away. ( I commend you to be good to women.)

Muslim women observe dress code and proper behavior as divinely based instructions from God and His messenger The Prophet Muhammad .These instructions are not male dominated or imposed. It is interesting to know that even the Bible encourages women to cover their head: "If a woman does not cover her head, she should have her hair cut off; and if it is a disgrace for a woman to have her hair cut or shaved off, she should cover her head." (1 Corinthians 11:6).

\section{Aspect of Legal and Political freedom:}

(1) Equality before the Law:

Both genders are entitled to equality before the Law and courts of Law. Justice is genderless (the Quran 5:38, 24:2, and 5:45). Women may have and right to express and independent legal entity in financial and other matters.

(2) Women participation in Social and political life:

Participation in these aspects is not forbidden. We can see general rule in social and political life is participation and collaboration of males and females in public affairs (Quran 9:71). We can observe sufficient historical evidences of muslim women participation, vote for the selection of rulers, in participating in public issues, helping in women legal policies. Muslim women worked in administrative positions, compete in scholarship and teaching, and even in the battlefield to help men. Such involvement in social and political affairs was conducted without the participants' losing sight of the complementary priorities of both genders and without violating Islamic guidelines of modesty and virtue. 


\section{STUDY OF STAUS BY COUNTRY}

Status of women by country according to data collected by Lauren Streib in the issue of Newsweek magazine.26 September 2011 a study was published on the status of women in countries around the world. The factors taken into account were legal justice, health and healthcare, education, economic opportunity, and political power. The rankings were determined by Lauren Streib by uniform criteria and available statistics. According to the study, the best and worst were:

\begin{tabular}{|c|c|c|c|c|c|c|c|c|}
\hline \multirow[b]{2}{*}{ Rank } & \multicolumn{8}{|c|}{ Topten } \\
\hline & Country & Overall & \multicolumn{2}{|c|}{ Justice } & Health & Education & Economics & Politics \\
\hline 1 & Iceland & 100.0 & \multicolumn{2}{|c|}{100.0} & 90.5 & 96.7 & 88.0 & 92.8 \\
\hline 2 & Sweden & 99.2 & \multicolumn{2}{|c|}{90.8} & 94.8 & 95.5 & 90.3 & 93.1 \\
\hline 3 & Canada & 96.6 & \multicolumn{2}{|c|}{100.0} & 92.7 & 92.0 & 91.0 & 66.9 \\
\hline 4 & Denmark & 95.3 & \multicolumn{2}{|c|}{86.1} & 94.9 & 97.6 & 88.5 & 78.4 \\
\hline 5 & Finland & 92.8 & \multicolumn{2}{|c|}{80.2} & 91.4 & 91.3 & 86.8 & 100.0 \\
\hline 6 & Switzerland & 91.9 & \multicolumn{2}{|c|}{87.9} & 94.4 & 97.3 & 82.6 & 74.6 \\
\hline 7 & Norway & 91.3 & \multicolumn{2}{|c|}{79.3} & 100.0 & 74.0 & 93.5 & 93.9 \\
\hline 8 & United States & 89.8 & \multicolumn{2}{|c|}{82.9} & 92.8 & 97.3 & 83.9 & 68.6 \\
\hline 9 & Australia & 88.2 & \multicolumn{2}{|c|}{80.7} & 93.3 & 93.9 & 85.3 & 65.1 \\
\hline 10 & Netherlands & 87.7 & 74 & & 95.0 & 99.0 & 83.0 & 68.4 \\
\hline & & & & Bottom te & & & & \\
\hline Rank & Country & & Overall & Justice & Health & Education & Economics & s Politics \\
\hline 165 & Chad & & 0.0 & 20.7 & 0.0 & 0.0 & 70.9 & 22.2 \\
\hline 164 & Afghanistan & & 2.0 & 8.4 & 2.0 & 41.1 & 55.3 & 16.6 \\
\hline 163 & Yemen & & 12.1 & 36.2 & 44.4 & 34.1 & 48.8 & 0.0 \\
\hline 162 & $\begin{array}{l}\text { Democratic Republic } \\
\text { Congo }\end{array}$ & of the & 13.6 & 6.5 & 11.4 & 45.1 & 67.8 & 27.2 \\
\hline 160 & Mali & & 17.6 & 22.7 & 29.9 & 25.8 & 64.3 & 49.8 \\
\hline 160 & Solomon Islands & & 20.8 & 0.0 & 53.6 & 86.5 & 46.0 & 1.9 \\
\hline 159 & Niger & & 21.2 & 26.5 & 32.9 & 47.5 & 58.6 & 31.3 \\
\hline 158 & Pakistan & & 21.4 & 49.7 & 49.6 & 34.0 & 50.7 & 19.3 \\
\hline 157 & Ethiopia & & 23.7 & 18.6 & 27.2 & 29.9 & 79.7 & 37.4 \\
\hline 156 & Sudan & & 26.1 & 21.1 & 29.4 & 70.6 & 54.5 & 40.8 \\
\hline
\end{tabular}

Status of women by country according to data collected by Lauren Streib in the issue of Newsweek magazine.26 September 2011 states Pakistan's position No 158. The result may be correct but reason is cultural constraints, social norms, lack of awareness, lack of education and poverty, wherever the circumstances will be same the result will be almost same. It is not particularly affiliated with religion Islam.

\section{Some Current Progress Has Been Seen In Women Status Of Pakistan}

Percentage of board members of Pakistani companies reached up to 4.6percent of a tad lower than the 4.7percent average in emerging Asian countries, but comparatively higher than neighboring 1percent in South Korea, 4.1percent in India and Indonesia, and 4.2percent in Malaysia, (Report on women in the boardrooms February 2011, ).

Now women participation in the National Assembly is 78 seats out of the 342 seats in Pakistan. This progress is the result of women education improvement. Last year in 2011,more than 42 percent of Pakistan's 2.6 million high school students were girls. In 1993 in Pakistani universities, women were about 22 percent of the 68,000 students in 2012, 47 percent of 1.1 million Pakistan's university students are women, (Higher Education Commission).

Pakistan's largest lenders, Habib Bank Half of all MBA graduates hired are women. "Parents are realizing how much better a lifestyle a family can have if girls work," senior executive Sima Kamil, HBL says , who oversees 1,400 branches as head of retail banking at Habib Bank.

Another a big organization Engro Chemicals, has 100 women in management positions, and due to change in workforce they for last year introduced flexible working hours, a day-care center, and a support group where female employees can discuss challenges they encounter. 
We see social norms in different societies by toys we give to our kids. Education also plays an integral role in the creation of gender norms. These norms usually help to structure of parenting and getting marriage with free will, especially in relation to work and choice of profession in and outside the home. There are some Cultural stereotypes as we believe that there is real relation between Feminism and the arts and women are only for Sexism and satisfaction. There is no other use of women. According to Massey, Douglas in "Categorically Unequal: The American Stratification System." NY: Russell Sage Foundation 2007, Cultural Stereotypes promote discrimination.

\section{Findings And Discussion}

This qualitative paper was aimed to know the truth about gender discrimination with the help of previous literature in Pakistan. We raised some questions and we conclude answers of those questions one by one. We can observe the current women status enjoyed by non -muslim women is not result of one event or due to kindness of society, it is knitted gradually through continuous struggle and sacrifices. Islam gave rights from its ignition there was no need for struggle to get rights from society. Currently active participation of muslim women is not visible in human sphere due to cultural effects. When and where religion will be practiced in all aspects all human beings will be remain in their circles and society will get be benefited.

During $2^{\text {nd }}$ world war women were needed to work more and only when society needed women contribution in earning, and due to continuous of technological change then modern civilizations made space for women. Islam made possible for women to work, vote, inherit, and possess property easily, not due to pressure of women, but rather because of its intrinsic truthfulness.

Effective implementation of legislative framework and effective coordination between various macro and micro level policies is needed to decrease the cultural impact on gender roles. Status of women by country according to data collected by Lauren Streib in the issue of Newsweek magazine.26 September 2011 Pakistan's position No 158. The result may be correct but reason of this status is cultural constraints, social norms, lack of awareness, lack of education and poverty, and in all over the world wherever the circumstances will be same the result will be almost same. It is not particularly affiliated with religion Islam.

\section{Findings}

The study provides evidence that human learn almost everything from its environment; chip of human brain is programmed by the culture, society and religion. Two areas particularly depict discrimination of gender, first on workplace (female literacy \& workforce participation) secondly discrimination at home.

It also highlights that there are inequity practices in some rural area in low earning families but same condition is not all over Pakistan proved by data. Religion Islam does not bound to progress of any tribe, race gender but social norms make people sensitive about it. Poverty forces people to set their priorities. Due to these priorities we see difference of both genders to access of in life sphere as health, profession, education. This difference is due to poverty, lack of education and awareness about religion, and this is common in all poor countries. In wealthy societies this difference is narrow.

The study's findings also explain reasons of inequality are lack of awareness, education and critical poverty. When people find basic needs out of reach they prefer to make their next generation to able to earn more and basically males are supposed to be strong and best skilled for earning and taking risk so that parents prefer their education, development and struggle. Parents try to safe their daughters from risks at any cost. Poverty plays a critical role in occupational choice and gender discrimination. Occupational concentration is larger among the working females. The findings of paper give insights about that there is difference between current status of women practiced and status and rights given by Islam religion.

Question 1.Is there gender discrimination exists in Pakistan?

Table 2:

\begin{tabular}{|l|l|l|}
\hline & $\mathbf{2 0 0 8 - 0 9}$ & $\mathbf{2 0 0 9 - 1 0}$ \\
\hline Participation Rate & & \\
\hline Male & $32.8 \%$ & $33.0 \%$ \\
\hline Female & $49.6 \%$ & $49.5 \%$ \\
\hline
\end{tabular}

Source: Labor Force Survey, relevant issues, Federal Bureau of Statistics 
Participation in economic activities of females is only 14.95 percent in 2008-2009 and increased 15.5percent in 2009-2010 which shows economic activities of females are limited in Pakistan and discrimination in economic field exists.

\section{Question 2}

\section{Are Gender Roles determined by society norms or by religion?}

Status of women by country according to data collected by Lauren Streib in the issue of Newsweek magazine.26 September 2011 states Pakistan's position No 158. The result may be correct but reason is cultural constraints, social norms, lack of awareness, lack of education and poverty, wherever the circumstances will be same the result will be almost same. It is not particularly affiliated with religion Islam.

Non-muslim woman is enjoying the current status due to pressure of women organizations, technological change and especially change was seen during the $2^{\text {nd }}$ world war gradually women participation was needed and due to war's aftereffects not due to kindness of society. Islam dignified the right status unconditionally not in compensation or reaction of some women organization. After all, this is the message of the All-Wise and All-Knowing God whose wisdom and knowledge are far beyond the ultimate in human thought and progress.

\section{Question 3 \\ What are reasons of gender discrimination? \\ Reasons behind inequality:}

1. Backward region without basic needs fulfillment

2. Relationship between poverty and employment

3. Relationship between education and insight

4. Lack of religious education

5. Effects of pre-divided cultures

6. Preference on the basis of future earning

Reasons of behaving in equally are lack of awareness, education and critical poverty. When people find basic needs out of reach they prefer to make their next generation to able to earn more and basically males are supposed to be strong and best skilled for earning and taking risk so that parents prefer their education, development and struggle. Parents try to safe their daughters from outside risks at any cost. Poverty plays a critical role in occupational choice and gender discrimination. Occupational concentration is larger among the working females.

Reasons of behaving inequally are lack of awareness, education and critical poverty. When people find basic needs out of reach they prefer to make their next generation to able to earn more and basically males are supposed to be strong and best skilled for earning and taking risk so that parents prefer their education, development and struggle. Parents try to safe their daughters from risks at any cost. Poverty plays a critical role in occupational choice and gender discrimination. Occupational concentration is larger among the working females.

\section{Conclusion}

Gender discrimination is prevalent in Pakistani society but causes of gender discrimination are usually misunderstood .Usually this discrimination is influenced by cultural norms and traditions, religion, region. Human beings belong to two sexes. Both genders are different biologically and socially, in their needs, fields of responsibilities. Physically a female is made to make family, relations, serve and trained human beings gently and male is made for hardships to construct, bear workload and struggle for earning. Both are equal in basic human rights but gentleness of woman need to be secure by strength of man .Both are made for different purposes so they can not be utilize in same manners. The effect of glass ceiling or artificial barriers for women is also a contributor to the gender wage gap or income disparity and is one of the barriers to reach women to top positions of job hierarchies (Chapel Hill 2001). According to The American People Census 2000: Gender Inequality at Work. New York: Russell Sage Foundation by Cotter, David, Joan Hermsen, and Reeve Vanneman, even we see in Super power America according to Census women's earnings are 71 percent of men's earnings in 1999 in America.

Human Philosophies have limited perspective and have been changed with the passage of time but the Divine origin Islam, which is far beyond from proceedings and change, which established such principles forever and not changeable are truth. Perception and fields of both genders is described by All-Wise and AllKnowing God whose wisdom and knowledge are far beyond the progressive knowledge of human beings.

Status of women by country according to data collected by Lauren Streib in the 26 September 2011 states Pakistan's position No 158. The result may be correct but reason is cultural constraints, social norms, lack of 
awareness, lack of education and poverty, wherever the circumstances will be same the result will be almost same. It is not particularly affiliated with religion Islam.

It is really tough to measure the degree of the effect of religion and cultural norms; religion is used for political purposes in this area because Islam is not being prevalent fully in Pakistan still. The intent of this paper is to draw a causal relationship between Islamic concept of women status and the traditional role of women in Pakistan, which is defined by influence of cultural norms and traditions by centuries.

There are inequity practices in some rural area in low earning families but same condition is not all over Pakistan proved by data. Religion does not bound to progress of any tribe, race gender but social norms make people sensitive about it. Poverty forces people to set their priorities. Due to these priorities we see difference between men and women in chances of education, health, employment and participation in life sphere. This difference is due to poverty, lack of education and awareness about religion, and this is common in all poor countries. In wealthy societies this difference is narrow.

People practice what they learn from society, culture and social norms. This is society which chooses priorities in gender role "not religion.

\section{Future Recomendations}

Real gender role perception is essential for implementation of legislative framework effectively. Effective coordination between various macro level policies and the gender dimensions of the impact, Analysis of macro-micro linkages of the policies, particularly with reference to gender so that population must act according to Islam to provide true picture of muslims. In Pakistan Islam has not been practiced in full extent generally it is utilized only for slogans and political issues that's why some norms become more important that religion. It is needed to make difference between what is practiced under the pressure of society and what should be practiced originally according to the religion of population. Currently labor force participation is not more than 15 percent in Pakistan. Besides other reasons gender discrimination and low literacy rate of females are main in women workforce participation. This qualitative paper was based on previous literature and historical references. Time and resources were constraints of it. It will be value added for coming researchers who have opportunity for future research to be carried out on these areas to highlight the truth about gender discrimination and roles of women and men so society can utilize full pool of capabilities of population.

If we see in a true muslim society deeply all human and needful rights are given to a muslim lady but only fields of responsibility and roles of man and woman is different in society as per Quran This research paper gives guide line to the academia researcher and experts of policy makers to analyze the situation in right perspective while making policies and projects in future. This research paper will also help to realize the women capacity, need for women employment at certain limits in certain professions. For the sack of a balanced society it is need of hour to understand that that men and women are mentally equally capable but their fields of responsibilities are different, men are responsible for earning whereas women have to keep the home and manage household affairs on priority but they are free in their decision making, contract binding, property holding earning if needed.

Investment in mass education is the only way to get ride of paradoxes of gender discrimination and carving a true perspective of women status in developing countries like Pakistan. Unlikely Pakistan remained grossly underinvested in education, and especially in, girls' education which can be foundation stone of comprehensive change of a society to decrease the gender discrimination. Educated women are base of awareness to ending gender bias; make them financially strong to reduce the poverty which is root cause of gender discrimination in Pakistan and even make it worst in the developing world.

\section{Implications}

On the bases of literature review findings of this study are beneficial for practicing muslims and also for non muslims to understand the true sense of gender roles in Pakistan. This is helpful to understand the women role in society where religion is prevalent in its true form This research is useful for explaining and identifying that many social forces affect the status of women in societies as education, awareness, poverty, culture. Historically Islam gave a status and rights to every human being included woman clearly but status of women in society has been shaped by the influence of culture, tradition and awareness in all over the world. Usually all over the world the status of a muslim woman misinterpreted and painted in disguised shape.

\section{Value / Originality}

This research, reflecting on the women status practiced in society vs awarded by religion in a patriarchal society like Pakistan, is one of few studies conducted in the South Asian region to utilize an insight given by religion to enrich understanding of the truth about gender discrimination. It therefore adds value by a fair evaluation of literature by exploring aspects of women status in civilizations before Islam and what is contribution of Islam toward the reinstatement of woman's rights and human rights as well. We need to take this 
issue historically to know how women lived their lives in general in past religions, preceded Islam (before 610 $\mathrm{AD})$ that is novel and significant.

\section{Refrences}

[1] Ahl, H. (2006). 'Why research on women entrepreneurs needs new direction'. Entrepreneurship Theory and Practice, 30(5), 595-621.

[2] Ashutosh Misra,( MMA 15-Point Manifesto) reprinted in "Rise of Religious Parties in Pakistan: Causes and Prospects," Strategic Analysis 27, no. 2 (April/June 2003)

[3] Burstein, Paul. "Equal Employment Opportunity: Labor Market Discrimination and Public Policy." Edison, NJ: Aldine Transaction, 1994.

[4] Cotter, David, Joan Hermsen, and Reeve Vanneman. The American People Census 2000: Gender Inequality at Work. New York: Russell Sage Foundation, 2000.

[5] Cotter, David, Joan Hermsen, Seth Ovadia and Reeve Vanneman. "Social Forces: The Glass Ceiling Effect." Chapel Hill, NC: University of North Carolina Press, 2001.

[6] Esposito (2004), p. 339

[7] Elder, G.H., Jr., (1995). "The Life Course Paradigm: Social Change and Individual Development.” In Moen, P., G.H. Elder, Jr., and K. Lüscher, eds. Examining Lives in Context: Perspectives on the Ecology of Human Development. Washington, D.C: American Psychological Association, 599-618.

[8] Encyclopedia of religion, second edition, Lindsay Jones, p.6224, ISBN 0-02-865742-X

[9] Goldin, Claudia, and Lawrence F. Katz. "On The Pill: Changing the course of women's education." The Milken Institute Review, Second Quarter 2001: p3.

[10] Hurst, Charles, E. Social Inequality. 6th. Boston: Pearson Education, Inc., 2007.

[11] Hamdun Dagher : The Position of Women in Islam

[12] Jacobs, Jerry. Gender Inequality at Work. Thousand Oaks, CA: SAGE Publications, 1995.

[13] John Esposito, Islam: The Straight Path p. 79

[14] Jamal Badawi's The Status of Woman in Islam and Gender Equity in Islam. compiled by Mostafa Malaekah, Women in Islam,

[15] Khilji, S. E. (1999). 'Management in Pakistan'. In M. Warner (ed.), International Encyclopedia of Business and Management. London: International Thomson Press.

[16] King and Mason, Engendering Development: Chamlou, Gender, and Development in the Middle East and North Africa.

[17] Lindsay Jones, p.6224

[18] Massey, Douglas. "Categorically Unequal: The American Stratification System.” NY: Russell Sage Foundation, 2007.

[19] Majid Khadduri, Marriage in Islamic Law: The Modernist Viewpoints, American Journal of Comparative Law, Vol. 26, No. 2, pp. 213-218

[20] Rehana Siddique Gender Issues in Pakistan,The MIMAP Gender Network Research Agenda,Presentation for the GDN Panel Discussion on Gender and Economic Reforms, 30 January 2004, New Delhi, India , ,Pakistan Development Economics, Islamabad, Pakistan

[21] Sherri Grasmuck and Rosario Espinal. "Market Success or Female Autonomy?" Sage Publications, Inc, 2000.

[22] Vedior,Women 'earn less than men across the globe', 4 March 2008

[23] http://www.alastairmcintosh.com/articles/2000_watt.htm. Retrieved 30 August 2011.

[24] Interview with Prof William Montgomery Watt". Alastairmcintosh.com. 27 May 2005.

[25] Wood, W., \& Eagly, A. H. (2010). Gender identity. In M. R. Leary \& R. H. Hoyle (Eds.), Handbook of individual differences in social behavior (pp. 109-125). New York: Guilford.

[26] Wood, Julia. Gendered Lives. 6th. Belmont, CA: Wadsworth/Thomson Learning, 2005.

[27] Zeba A. Sathar et al., 2002

[28] Narrated in Ibn Majah, \#1978, and Al-Tirmizi, \#3895.

[29] Narrated in Saheeh Muslim, \#2548, and Saheeh Al-Bukhari, \#5971.

[30] NPF and PRB, Country Profiles for Population and Reproductive Health: Policy Developments and Indicators (United Nations Population Fund / Population Reference Bureau, 2003), p.147 